\title{
FREKUENSI ASUPAN MAKANAN SUMBER SERAT DAN KEJADIAN KONSTIPASI PADA LANSIA ADVENT DAN NON-ADVENT
}

\author{
Jeanette Imanuela Diva Sulistiono, Evelin Malinti \\ Fakultas Ilmu Keperawatan, Universitas Advent Indonesia \\ *email: jeanette.diva@yahoo.com
}

\begin{abstract}
Aging is a process in which the immune system decreases, the manifestation of physical weakness and various changes in body organs. In the elderly, the aging process is sure to happen and one of them is a decrease in the gastrointestinal system function which can cause constipation problems. The purpose of this study was to determine the frequency of fiber intake and the incidence of constipation and characteristic of feces in the Adventist and Non-Adventists elderly. The study utilized an observational analytic with cross-sectional design. The respondents in this study was 60 elderly obtained by purposive sampling technique. Data collection using food-frequency questionnaires, constipation events and the Bristol Stool Chart. The results of the study with independent t-test showed a significant difference (p $<0.50)$ in the frequency of food intake of fiber sources of the two groups. Incidence of constipation and characteristic of feces in the two groups also showed a significant difference $(\mathrm{p}<0.50)$. Thus the frequency of food intake of fiber sources influences the characteristics of feces and the incidence of constipation. Further research can evaluate eating patterns and types of food that affect constipation in the elderly.
\end{abstract}

Keywords: Constipation, Elderly, Fiber intake, Stool characteristics

\begin{abstract}
Abstrak
Penuaan adalah proses dimana sistem imunitas menurun, terjadinya kelemahan fisik dan berbagai perubahan dalam organ tubuh. Pada lansia, proses penuaan pasti terjadi dan salah satunya adalah penurunan sistem gastrointestinal yang bisa mengakibatkan masalah konstipasi. Tujuan penelitian ini adalah untuk mengetahui frekuensi asupan serat dan kejadian kostipasi serta karakteristik feses pada lansia Advent dan Non-Advent. Metode penelitian yang digunakan yaitu observasional analitik dengan desain potong lintang. Responden pada penelitian ini sebanyak 60 orang yang diperoleh dengan teknik purposive sampling. Pengumpulan data menggunakan kuesioner food-frequency, kejadian konstipasi dan Bristol Stool Chart. Hasil penelitian dengan uji t-independen menunjukan perbedaan yang signifikan $(\mathrm{p}<0.50)$ pada frekuensi asupan makanan sumber serat kedua kelompok. Kejadian konstipasi dan karakteristik feses pada kedua kelompok juga menujukkan perbedaan yang signifikan $(\mathrm{p}<0.50)$. Dengan demikian frekuensi asupan makanan sumber serat mempengaruhi karakteristik feses dan kejadian konstipasi. Penelitian lebih lanjut dapat mengevaluasi pola makan dan jenis makanan yang mempengaruhi konstipasi pada lansia.
\end{abstract}

Kata kunci: Asupan serat, Karakteristik feses, Kejadian konstipasi, Lansia 


\section{Pendahuluan}

Lansia merupakan proses penuaan dan bukan penyakit. Proses ini ditandai dengan penurunan kemampuan tubuh untuk beradaptasi dengan perubahan dari dalam dan luar tubuh (Abdul, 2016). Pada tahap ini lansia akan mengalami banyak masalah yaitu, berawal dari kemunduran sel-sel tubuhnya yang menyebabkan fungsi organ tubuh dan daya tahan tubuh menurun sehingga menimbulkan masalah kesehatan (Siti, 2016). Perubahan fungsi fisiologis lansia diantaranya penurunan fungsi pencernaan (Irnawati \& Ade, 2014). Penurunan fungsi dan struktur sistem gastrointestinal lansia dapat menyebabkan konstipasi pada lansia (Erna, Silvia \& Setho, 2019).

Berkurangnya fungsi indera pengecap dan keadaan gigi yang sudah tidak lengkap menyebabkan berkurangnya nafsu makan pada lansia (Agung, 2015). Konstipasi yang terjadi pada lansia cenderung terjadi oleh karena asupan serat yang kurang dan perubahan fungsi gastrointestinal (Muzakar \& Bella, 2018). Penyebab lain dari konstipasi pada lansia antara lain diet rendah serat, terlalu sering memakan daging, kurang minum dan stress (Vita, Zen \& Suyatno, 2015). Kurang aktifitas fisik serta sering menahan keinginan untuk buang air besar juga dapat menyebabkan konstipasi (Budi \& Dian, 2016).

Penelitian yang dilakukan oleh Siti (2014), menunjukkan bahwa lansia yang diberi diit tinggi serat tidak mengalami konstipasi sedangkan lansia yang tidak diberi diit tinggi serat mengalami konstipasi. Pada penelitian lain menunjukkan bahwa serat yang didapat dari mengkonsumsi buah-buhan serta sayur-sayuran merupakan sumber serat yang paling baik dan mudah larut sehingga tidak menimbulkan konstipasi pada lansia (Olomo, 2017).

Penelitian lain mengatakan bahwa asupan vitamin $\mathrm{C}$ dapat menangani konstipasi karna pada dosis vitamin $C$ yang tinggi berfungsi sebagai pencahar yang mengakibatkan feses menjadi lebih lunak ( Ittaq, 2015). Selain itu pada penelitian tentang dampak penggunaan kedelai pada makanan tradisional berhubungan dengan kesehatan dan status gizi lansia menunjukkan bahwa penambahan kedelai pada menu makanan

Published by Faculty of Nursing | Universitas Klabat lansia sangat penting dan menjaga keseimbagan nutrisi makro (Komal, Pallavi \& Neha, 2018).

Sumber serat makanan yang paling baik terdapat dapa buah dan sayuran (Dewi, 2013). Asupan serat yang cukup mengurangi resiko terkena diabetes, penyakit kardiovaskular, penyakit kanker tertentu, menambah berat badan dan konstipasi (Jordan, Paige, Jessica, Vanssa, Kevin, Tia, Latha, Lisa, \& Dominik, 2014). Serat makanan yang tinggi adalah acuan untuk menjaga kesehatan sistem pencernaan kita (Kusharto, 2006)

Masalah konstipasi sering dianggap remeh dan disepelekan oleh kebanyakan orang. Banyak individu yang berfikir bahwa konstipasi yang dialami dapat sembuh dengan sendirinya (Amelia \& Bambang, 2017), padahal situasi yang serius dapat terjadi, seperti impaksi dan obstruksi bila kondisi konstipasi dibiarkan (Marrelli, 2008). Konstipasi juga dapat menandakan adanya gejala kanker usus besar (Abednego, 2013). Serat dibutuhkan lansia untuk melancarkan pencernaan yang sering mengalami konstipasi (Lenny, 2013). Serat yang terkandung dalam makanan membantu mendorong peristaltik usus (Merryana \& Bambang, 2016). Konstipasi pada lansia dapat diatasi dengan mengubah pola hidup dan perilaku lansia (Subrata, 2015).

Berdasarkan studi pendahuluan didapati bahwa lansia Advent lebih suka memilih jenis makanan berbahan dasar tumbuh-tubuhan. Hal ini telah menjadi kebiasaan dan suatu kepercayaan terhadap ajaran agama tentang pola makan yang sehat. Sehingga peneliti tertarik untuk mengetahui apakah ada perbedaan frekuensi asupan serat dan kejadian konstipasi pada lansia Advent dan Non-Advent.

\section{Bahan dan metode penelitian}

Metode penelitian yang digunakan dalam penelitian ini adalah observasional analitik dengan desain potong lintang. Sampel penelitian diambil menggunakan teknik purposive sampling, yaitu lansia Advent dan Non-Advent berumur 60-86 tahun baik laki-laki ataupun perempuan yang kependudukannya berada di Kecamatan Parongpong.

Dalam penelitian ini responden dibagi dalam 2 kelompok. Kelompok 1 terdiri dari 30 
lansia Advent dengan jumlah responden laki-laki 9 orang dan perempuan 21 orang. Kelompok 2 terdiri dari 30 orang Non-Advent dengan jumlah responden laki-laki 15 orang dan responden perempuan 15 orang.

Pengambilan data penelitian ini menggunakan kuesioner food-frequency, kejadian konstipasi dan Bristol Stool Chart. Pengolahan data untuk frekuensi asupan makanan sumber serat menggunakan skala likert dengan pembagian: tidak pernah, jarang, kadang-kadang, sering dan selalu. Data konstipasi diperoleh dengan jawaban ya dan tidak untuk pernyataan tentang konstipasi. Karakteristik feses responden dinilai dari gambar yang dipilih oleh responden dari Bristol Stool Chart.

Proses pengumpulan data diawali dengan mendatangi calon responden di rumah masingmasing dan diberi penjelasan tentang maksud dan tujuan penelitian. Setiap responden yang setuju untuk ikut serta dalam penelitian diminta untuk menandatangani informed consent.

\section{Hasil}

Perbedaan rata-rata frekuensi asupan makanan sumber serat antara kedua kelompok dapat dilihat dalam table 1 . Perbedaan rata-rata frekuensi asupan makanan sumber serat antara lansia Advent dan Non-advent dilakukan dengan uji $t$-independent.

\section{Tabel.1}

Perbedaan rata-rata frekuensi asupan makanan sumber serat antara lansia Advent dan NonAdvent

\begin{tabular}{lllll}
\hline $\begin{array}{l}\text { Sumber } \\
\text { Serat }\end{array}$ & Kelompok & Mean & SD & P \\
\hline $\begin{array}{l}\text { Padi- } \\
\text { padian }\end{array}$ & Advent & 2.30 & 0.65 & 0.000 \\
& $\begin{array}{l}\text { Non- } \\
\text { Advent }\end{array}$ & 1.73 & 0.44 & \\
Kacang- & Advent & 1.53 & 0.57 & 0.035 \\
kacangan & $\begin{array}{l}\text { Non- } \\
\text { Advent }\end{array}$ & 1.23 & 0.50 & \\
& $\begin{array}{l}\text { Advent } \\
\text { Sayur- }\end{array}$ & 2.56 & 0.56 & 0.000 \\
sayuran & $\begin{array}{l}\text { Non- } \\
\text { Advent }\end{array}$ & 1.83 & 0.37 & \\
Buah- & $\begin{array}{c}\text { Advent } \\
\text { buahan }\end{array}$ & 1.83 & 0.37 & 0.000 \\
& $\begin{array}{c}\text { Non- } \\
\text { Advent }\end{array}$ & 1.16 & 0.37 & \\
\hline
\end{tabular}

Published by Faculty of Nursing | Universitas Klabat
Perbedaan rata-rata kejadian konstipasi dan karakteristik feses antara lansia Advent dan Non-Advent dapat dilihat pada tabel 2. Perbedaan rata-rata kejadian konstipasi dan karakteristik feses lansia Advent dan Non-Advent dilakukan dengan uji t-independent.

Tabel.2

Perbedaan rata-rata kejadian konstipasi dan karakteristik feses pada kelompok Advent dan Non-Advent

\begin{tabular}{lcccc}
\hline & $\begin{array}{c}\text { Kelomp } \\
\text { ok }\end{array}$ & Mean & SD & p \\
\hline Kejadian & Advent & 2.30 & 0.65 & 0.000 \\
Konstipasi & $\begin{array}{c}\text { Non- } \\
\text { Advent }\end{array}$ & 1.73 & 0.44 & \\
Karakteri & $\begin{array}{c}\text { Advent } \\
\text { Non- }\end{array}$ & 1.53 & 0.57 & 0.000 \\
& 1.23 & 0.50 & \\
\hline
\end{tabular}

\section{Pembahasan}

Tabel 1 menunjukkan bahwa rata-rata frekuensi asupan sumber serat dari padi-padian pada kelompok lansia Advent adalah 2.30 yang termasuk kategori sering. Sedangkan pada kelompok lansia Non-Advent didapati frekuensi asupan makanan sumber serat padi-padian yaitu, kadang-kadang dengan rata-rata 1.73. Selanjutnya rata-rata asupan makanan sumber serat dari jenis kacang-kacangan, kelompok lansia Advent dengan angka 1.53 yaitu, kadangkadang. Pada kelompok lansia Non-Advent, didapati angka 1.23 yang diartikan sebagai jarang dikonsumsi. Lalu pada rata-rata asupan makanan sumber serat jenis sayur-sayuran, pada kelompok Lansia Advent ditemukan rata-rata 2.56 yaitu frekuensinya selalu. Sedangkan pada kelompok lansia Non-Advent rata-rata 1.83 yang berarti frekuensinya kadang-kadang. Frekuensi asupan makanan sumber serat jenis buah-buahan pada kelompok lansia Advent dengan rata-rata 1.83 yaitu dalam kategori kadang-kadang. Sedangkan pada kelompok lansia Non-Advent rata-rata 1.16 atau kategori jarang.

Hasil uji t-independent pada frekuensi asupan makanan sumber serat baik dari padipadian, kacang-kacangan, sayur-sayuran, dan buah-buahan antara kedua kelompok menunjukkan bahwa $p=.000$. Hal ini menunjukkan bahwa terdapat perbedaan yang 
signifikan pada frekuensi asupan makanan sumber serat antara kelompok lansia Advent dan Non-Advent. Kelompok lansia Advent memiliki frekuensi asupan makanan sumber serat yang lebih tinggi dibanding kelompok lansia NonAdvent.

Pada tabel 2 dapat dilihat perbedaan ratarata kejadian konstipasi dan perbedaan rata-rata karakteristik feses kedua kelompok. Rata-rata kejadian konstipasi pada kelompok lansia Advent yaitu tidak pernah, dengan angka rata-rata 0.00 . Sedangkan didapati ada kejadian konstipasi pada kelompok lansia Non-Advent, dengan rata-rata 0.46. Dilihat dari karakteristik feses, dalam kelompok lansia Advent rata-rata karakteristik feses didapati feses berbentuk seperti sosis atau pisang yang dikupas kulitnya, halus dan lembut dengan rata-rata 3.39. Pada kelompok lansia NonAdvent ditemukan rata-rata karakteristik feses berbentuk seperti sosis tetapi bergumpal-gumpal dengan angka 2.46 .

Hasil uji t-independent menunjukkan perbedaan signifikan antara kedua kelompok pada kejadian konstipasi $(\mathrm{p}=.000)$ dan karakteristik feses $(\mathrm{p}=.000)$. Hasil penelitian ini menunjukkan bahwa ada pengaruh frekuensi asupan makanan sumber serat dengan kelancaran buang air besar. Penelitian yang dilakukan kurang lebih 6 tahun lalu yaitu, pemberian diit tinggi serat pada lansia dengan konstipasi menunjukkan bahwa ada pengaruh pemberian diit tinggi serat terhadap konstipasi pada lansia (Sholikhah,2013). Pemberian buah tinggi serat juga mempengaruhi penurunan tingkat konstipasi pada lansia (Afriani, Sulendri \& Laraeni, 2017).

Konstipasi merupakan kondisi dimana frekuensi buang air besar yang rendah dengan karakteristik feses yang keras sehingga memberi ketidaknyamanan dan rasa terganggu pada penderitanya (Sari \& Wirjatmadi, 2016). Kurangnya asupan serat dapat menimbulkan konstipasi dan sekitar 4\%-30\% masyarakat pada kelompok usia 60 tahun keatas mengalaminya, sehingga asupan serat yang cukup diperlukan untuk dapat mempermudah proses buang air besar (Yulianti \& Najma 2017).

Hasil uji perbedaan kejadian kostipasi dan karakteristik feses pada kelompok Advent dan Non-Advent juga menunjukkan bahwa ada perbedaan. Semakin sering frekuensi asupan

Published by Faculty of Nursing | Universitas Klabat makanan sumber serat maka semakin sedikit kejadian konstipasi yang timbul dan karakteristik feses juga tidak akan keras sehingga proses buang air besar akan lancar. Mencegah konstipasi melalui cara yang sederhana adalah dengan meningkatkan asupan makanan tinggi serat kedalam tubuh kita (Abednego, 2013).

\section{Kesimpulan}

Hasil penelitian ini menunjukkan bahwa kelompok lansia Advent memiliki frekuensi asupan makanan sumber serat yang lebih tinggi dari kelompok lansia Non-Advent. Kelompok lansia Advent tidak mengalami konstipasi sedang kelompok lansia Non-Advent mengalami konstipasi dengan karakteristik feses bergumpal. Terdapat perbedaan signifikan dalam hal asupan makanan sumber serat, kejadian konstipasi dan karakteristik feses diantara kedua kelompok. Dengan demikian penelitian ini menyimpulkan bahwa asupan serat yang cukup dapat mencegah kejadian konstipasi pada lansia. Penelitian lebih lanjut dapat dilakukan dengan mengevaluasi pola makan dan jenis makanan yang mempengaruhi konstipasi pada lansia.

\section{Daftar Pustaka}

Abiola, O.J. (2017). The Impact Of Fruits And Vegetables Consumption On Healthy Living Of The Elderly In Ikire South West, Nigeria. International journal of Science, Engineering \& Environmental Technology (IJOSEET). 2(7): $45-54$

Adriani, M. \& Wirjatmadi, B. (2016). Pengantar Gizi Masyarakat. Jakarta. KENCANA

Afriani,Sulendri, \&Laraeni. (2017). Pengaruh Pemberian Jus Jambu Biji Dan Tomat Terhadap Lansia Yang Mengalami Konstipasi Di Panti Sosial Tresna Werdha Puspakarma Mataram. Jurnal Gizi Prima. 2(2):86-93

Azalista, IA. (2015). “Asupan Kalsium, Vitamin C Dan Kejadian Konstipasi Pada Lansia Di Panti Wreda Bhakti Dharma Surakarta" . Fakultas Ilmu Kesehatan. Universitas Muhammadiyah Surakarta. Surakarta

Bangun, Abednego. (2014). Sehat Dan Bugar Hingga Lansia. Bandung. Indonesia Publishing House 
Chauhan, K., Mehta, P. \& Garg, N. (2018). Impact Evaluation Study Of Soya Incorporated Traditional Food Items On Health And Nutritional Status Of Institutionalized Elderly Of Vadodara. Asian Resonance. 7(3):98-103

Dalal, S. (2015). Effectiveness Of Health Education On Prevention And Management Of Constipation In Terms Of Knowledge Among Geriatric People In A Selected Old Age Home Kolkata. J of Evolution of Med and Dent Sci. 4(2):11215-11223

Jusup, L. (2011). Fit For Life - Kiat Menghadapi Masalah Kesehatan Lansia. Jakarta. PT Gramedia Pustaka Utama

Kholifah, SN. (2016). Keperawatan Gerontik. Jakarta: Pusdik SDM Kesehatan

Kholifah, SN. (2016). Keperawatan Gerontik. Jakarta. Pusdik SDM Kesehatan

Kusharto, Clara M. (2004). Serat Makanan Dan Perannya Baggi Kesehatan. Jurnal Gizi dan Pangan. 1(2):45-54

Marrelli, TM. (2000). Buku Saku Dokumentasi Keperawatan. Kedokteran EGC

Muzakar \& Audina, B. (2018). Pengaruh Pemberian Jus Alpukat (Persea Gratissima) Terhadap Perubahan Konstipasi Pada Lansia Di Panti Tresna Werdha Teratai of Palembang City in 2016. Publukasi Penelitian Terapan Dan Kebijakan. 1(1):3035

Pandji, D. (2012). Menembus Dunia Lansia. Jakarta. PT Alex Media Komputindo Kelompok Gramedia - JakartaJusup, L. 2010. Rahasia Tetap Muda Hingga Lasia. Jakarta. PT Gramedia Pustaka Utama.

Pradani, VR., Rahfiludin, MZ. \& Suyatno. (2015). Hubungan Asupan Serat, Lemak, Dan Posisi Buang Air Besar Dengan Kejadian Konstipasi Pada Lansi. Jurnal Kesehatan Masyarakat (e-Journal). 3(3):257265

Sari, ADK. \& Wirjatmadi, B. (2017). Hubungan Aktivitas Fisik Dengan Kejadian KonstipasiPada Lansia Di Kota Madiun. Media Gizi Indonesia. 11(1):40-47

Schimer, JK. et al. (2014). Cost Savings Of Reduced Constipation Rates Attributed To Increased Dietary Fiber Intakes: A DecisionAnalytic Model. BMC Public Health. 14:374

Published by Faculty of Nursing | Universitas Klabat
Sholikhah, S. (2014). Pengaruh Diet Tinggi Serat Terhadap Konstipasi Pada Lansia Di Dukuh Patihan Desa Trucuk Kecamatan Trucuk Kabupaten Bojonegoro Tahun 2013. SURYA. 7(1):107-112

Siyoto, AMS. (2016). Pendidikan Keperawatan Gerontik. Yogyakarta: CV ANDI OFFSET

Sutomo, B. \& Kurnia, D. (2016). 378 Jus \& Ramuan Herbal: Tumpas Penyakit Ringan sampai Berat. Depok. PT Kawan Pustaka

Tamba, I. \& Gultom ACH. (2014). Susunan Variasi Makanan Kaitannya Dengan Tingkat Selera Makan Lansia Di Panti Werdah Yayasan Guna Budi Bakti Medan Labuhan Jurnal Saintika. 14(2):161-172

Wahyuni, ED., Suwandi SL. \& Hadisuyatmana, S. (2019). Pijat Perut Menurunkan Tingkat Konstipasi Pada Lanjut Usia. Critical, Medical And Surgical Nursing Journal. DOI: 10.20473/cmsnj.v6i2.12833

Wirjatmadi \& Sari. (2016). Hubungan Aktivitas Fisik Dengan Kejadian Konstipasi Paa Lansia Di Kota Madiun. Media Gizi Indonesia. 11(1):40-47

Yoga, MAPA. (2015). The Association Between Intake Of Energy, Proteinandphysical Activitywith Nutritional Status Of Elderly People. J Majority. 4(2):52-59

Yuliati \& Najma. (2017). Pengaruh Air Rebusan Daun Pepaya Terhadap Konstipasi Lansia Studi Kasus Di Panti Sosial Tresna Werdha Budi Mulya 02 Cengkareng. Indonesia Jurnal Perawat. 2(1):45-49 